\title{
A correlation study of the expression of HA-CD44st and HER-2 in breast cancer
}

This article was published in the following Dove Press journal:

OncoTargets and Therapy

\author{
Lu Ying Zhi',* \\ Zhang $\mathrm{Xu}^{2, *}$ \\ Li Ning ${ }^{3}$ \\ Li Jia Jin ${ }^{1,4}$ \\ Yan Hai Cui' \\ Huang Guan Hong' \\ Xin Jian Fang'
}

'Department of Medical Oncology, the Second People's Hospital of Lianyungang (Lianyungang Hospital

Affiliated to Bengbu Medical College), Lianyungang, Jiangsu 222000, People's

Republic of China; ${ }^{2}$ Molecular Biology Laboratory, Medical College, Jiangsu

University, Jiangsu 20I20I3, People's

Republic of China; ${ }^{3}$ Department

of Surgery, the First People's

Hospital of Lianyungang, Jiangsu

222000, People's Republic of China;

${ }^{4}$ Department of Information Center, the Second People's Hospital of Lianyungang (Lianyungang Hospital Affiliated to Bengbu Medical College), Lianyungang, Jiangsu 222000, People's Republic of China

*These authors contributed equally to this work

Correspondence: Xin Jian Fang; Huang Guan Hong Department of Medical Oncology, the Second People's Hospital of Lianyungang (Lianyungang Hospital Affiliated to Bengbu Medical College), No 4I, Hailian East Road, Lianyungang, Jiangsu 222000, People's Republic of China Tel +865I8 85776562 Email lygfxj@I26.com; xuzhang@ujs.edu.cn
Background: This study investigated the effect of hyaluronic acid (HA)-CD44st on the invasive ability of human breast cancer MCF-7 cells and the correlation between the expression of CD44st and human epidermal growth factor receptor-2 (HER-2) in postoperative breast cancer patients.

Materials and methods: MCF-7 cells transfected with the eukaryotic expression vector pcDNA3.1-CD44st (MCF/CD44st) were used to examine the effect of the activation of the HACD44st-transforming growth factor $\beta$ (TGF $\beta$ )-phosphatidylinositol-3-kinase (PI3K) signaling pathway on the invasive ability of MCF-7 cells. The expression of proteins related to this signaling pathway was assessed by flow cytometry, reverse transcription-polymerase chain reaction, and Western blotting, and the role of AP-1 in the pathway was investigated by electrophoretic mobility shift assay. The effect of pathway activation on the invasion of MCF-7 cells was assessed by Transwell assay, and CD44 expression in breast cancer tissue was detected by immunohistochemistry. Quantitative reverse transcription-polymerase chain reaction was used to detect the expression of CD44st and HER-2 in breast cancer tissue and their correlation was investigated.

Results: HA significantly upregulated HER-2 and TGF $\beta$ in MCF-7/CD44st cells, increased p-AKT expression and AP-1 activity, and promoted the invasive ability of tumor cells. CD44st mRNA expression had significant difference between breast cancer tissues and adjacent normal tissues $(P<0.05)$, and high expression of CD44st mRNA was closely correlated with HER-2 expression in breast cancer tissues.

Conclusion: Binding of HA to the CD44st receptor may regulate the invasiveness of MCF-7 cells through the CD44st/TGF $3 / \mathrm{PI} 3 \mathrm{~K} / \mathrm{AP}-1$ signaling pathway with increased expression of TGF $\beta$ and HER-2. The expression of CD44st mRNA is correlated with HER-2 expression in postoperative breast cancer patients.

Keywords: CD44st, TGF $\beta$, HER-2, invasion, breast cancer

\section{Introduction}

CD44st is a member of the CD44 family, which is a major receptor for hyaluronic acid (HA). The human CD44 gene is located on the short arm of chromosome 11, and the complete CD44 gene spans $\sim 50 \mathrm{~kb}$ on the chromosome. CD44 family members mediate intracellular signal transduction by interacting with cytoskeleton proteins. An increasing number of studies have shown that CD44 is not only a biomarker of tumor stem cells but also is directly involved in the development of cancer. ${ }^{1}$ Many CD44 subtypes have been identified to date, and the most common subtype is standard CD44 (CD44s), which consists of the constant region exons 1-5, 16-18, and 20; other common subtypes include PMeta-1 and pMeta-2. ${ }^{2}$ We cloned a novel short-tail isoform of CD44s (CD44st) from the multidrug resistant breast cancer cell line MCF-7/Adr. The isoform contains exons 1-4, 16-17, and 1-205 bp of exon 18 (GeneBank: FJ216964). 
In previous work from our group, we showed that HA can interact with CD44st in MCF-7/CD44st cells, leading to increased secretion of matrix metalloproteinase (MMP)-2 and MMP-9 through the mitogen-activated protein kinase (MAPK) signaling pathway, resulting in increased tumor cell invasiveness. ${ }^{3}$ Further studies showed that HA can activate the transcription factor NF- $\mathrm{KB}$ by upregulating CD44st to induce the secretion of MMP-2 and MMP-9 by multidrugresistant cells, affecting the invasiveness of tumor cells. ${ }^{4}$

Transforming growth factor $\beta$ (TGF $\beta$ ) can promote or inhibit the progression of breast cancer in different environments. In early stage breast cancer, TGF $\beta$ inhibits the proliferation of tumor cells; however, in the advanced stages, tumor cells develop resistance to TGF $\beta$, and TGF $\beta$ can promote tumor metastasis. Although the mechanism underlying the dual role of TGF $\beta$ in tumors remains unclear, studies suggest that binding of TGF $\beta$ to its receptors (TGF $\beta R 1$ or TGF $\beta R 2$ ) is critical for the signal transduction cascade..$^{5-7}$ TGF $\beta$ is synthesized in the form of a precursor that is cleaved to release the N-terminal region, latency-associated peptide (LAP); LAP binds to mature TGF $\beta$ homodimers and promotes the binding of another protein, latent TGF $\beta$-binding protein (LTBP). TGF $\beta$ in the TGF $\beta / \mathrm{LAP} / \mathrm{LTBP}$ complex is in an inactive state and cannot bind to TGF $\beta R{ }^{8}$

TGF $\beta$ is one of the downstream target proteins of the signal transduction pathway mediated by HA-CD44. The HA receptor $\mathrm{CD} 44$ mediates the cellular proliferation reaction induced by TGF $\beta 1$, which is associated with the conjugation of EGFR and CD44 promoted by the upregulation of HA and the strengthening of the MAPK/extracellular signalrelated protein kinase (ERK) signaling pathway. ${ }^{9}$ Treatment of MCF-7-B5 cells, which positively express CD44, with $\mathrm{HA}$ results in the significant upregulation of TGF $\beta 2$, and its upregulation is closely associated with the invasiveness of tumor cells. ${ }^{10}$

Epithelial-mesenchymal transition (EMT) is a complex and tightly regulated process that confers mesenchymal cell properties to epithelial cells. ${ }^{11}$ During EMT, the changes in cellular behaviors and properties are mediated by EMTrelated transcription factors such as Snail/Slug and ZEB1/2, which promote the loss of epithelial components such as ankyrin and the production of mesenchymal proteins such as vimentin. These EMT transcription factors can be activated by many cytokines or growth factors including TGF $\beta .^{12}$ In addition to its role in EMT, the TGF $\beta$ pathway controls many normal and pathological processes, either through classical signaling cascades such as those mediated by Smad 2/3 or nonclassical signaling cascades involving non-Smad proteins such as PI3K-AKT and ERK 1/2.13,14

Human epidermal growth factor receptor-2 (HER-2)positive patients account for $15 \%-20 \%$ of all breast cancer patients. HER-2-positive breast cancer is characterized by high invasion and metastasis potential, and HER-2-positive patients have a poor prognosis. ${ }^{15}$ The anti-HER-2 monoclonal antibody $(\mathrm{mAb})$ trastuzumab can improve the prognosis of HER-2-positive breast cancer patients. ${ }^{16,17}$

In MCF-7 cells, binding of HA to CD44 mediates the interaction of CD44 with members of the HER family and leads to the overexpression of hyaluronidase synthase- 2 or MMPs, which further increase the phosphorylation of the HER-2 protein. ${ }^{18}$ Moreover, CD44-HER2 complex activation induced by CD44 increases the malignancy of tumor cells, ${ }^{19}$ and CD44 overexpression can induce trastuzumab-resistance in HER-2-positive breast cancer cells. ${ }^{20}$

CD44st, which was identified in the multidrug resistant cell line MCF-7/Adr, plays a role in tumor invasion and drug resistance. To shed light on this mechanism, we examined the effect of the HA-CD44st signaling pathway on the expression of TGF $\beta$, as well as how the HA-CD44st signal affects the activity of the downstream phosphatidylinositol-3-kinase (PI3K) pathway and the expression of HER-2. Semi-quantitative reverse transcription-polymerase chain reaction (RTPCR), real-time quantitative PCR (qPCR), gene sequencing, and immunohistochemistry were used to detect differences in the expression of CD44st between breast cancer tissues and paracancerous tissues and to analyze the correlation between the CD44st mRNA and the CD44 protein, as well as the correlation between the CD44st and HER-2 mRNAs. Our study provides a theoretical basis for the application of CD44st as a prognostic biomarker and the development of CD44st- or TGF $\beta$ - targeted therapeutics.

\section{Materials and methods}

\section{Cell lines}

The breast cancer cell line MCF-7 and the adriamycin-resistant breast cancer cell line MCF-7/ADR were purchased from the Cell Bank of Chinese Academy of Sciences (Shanghai, People's Republic of China).

\section{Sample information}

A total of 120 paraffin-embedded breast cancer tissue specimens were obtained from patients undergoing radical mastectomy between January 2010 and January 2012 (Lianyungang No 2 People's Hospital and Lianyungang 
Tumor Hospital). The samples included 105 cases of invasive ductal carcinoma and 15 cases of invasive lobular carcinoma. The corresponding paracancerous tissue specimens $(>5 \mathrm{~cm}$ away from the tumor tissue) served as controls.

\section{Main reagents}

The following reagents or kits were purchased from New England Biolabs, Inc. (Beverly, MA, USA): RT-PCR kit, Trizol, Opti-MEM-I Reduced Serum Medium (OPTI-MEM), Lipofectamine 2000 transfection kit New England Biolabs, Inc. (Beverly, MA, USA), the restriction endonucleases EcoRI and KpnI, RNA extraction kit for paraffin-embedded tissue (K1560-2), and reverse transcription cDNA synthesis kit (K1622). The following reagents or kits were purchased from Takara Bio, Inc. (Kusatsu, Japan): HA, T4 ligase, high fidelity Taq polymerase, 1640 medium, pMD19-T vector (6013), Taq DNA polymerase (RR066B), and fluorescent q PCR kit (RR066B). The following reagents or kits were purchased from Cell Signaling Technology, Inc. (Beverly, MA, USA): TGF $\beta$ antibody (3711), HER-2 antibody (2242), LY-294002 (9901), PI3 Kinase Class II Rabbit mAb, Phospho-NDRG1 (Ser330) (D3A12) Rabbit mAb, rabbit anti-human AKT antibody, and phosphorylated AKT antibody (3711). Transwell chambers were purchased from Corning Inc. (Corning, NY, USA). Matrigel was purchased from Becton Dickinson Biosciences (San Jose, CA, USA). Mouse anti-human CD44 mAb (14-0441) was purchased from Affymetrix Inc. (Santa Clara, CA, USA). A real-time PCR machine was purchased from Applied Biosystems (Foster City, CA, USA). The eukaryotic expression vector pcDNA3.1 was kindly donated by Prof Xu Wenrong from School of Basic Medical and Medical Technology of Jiangsu University.

\section{Methods}

CD44st plasmid construction and expression in MCF-7 cells were performed as described in a previous study. ${ }^{3}$

\section{Gene transfection and identification of CD44 expression}

One day before transfection, MCF-7 cells were seeded in a six-well plate at a density of $3.5 \times 10^{5} /$ well. The following groups were set up: negative control group (MCF-7), empty vector transfection control group (MCF-7/neo), and CD44st transfection group (MCF-7/CD44st). Transfection was performed according to the instructions of the Lipofectamine 2000 kit. At $48-72 \mathrm{~h}$ after transfection, the cells were collected, and the CD44 mRNA and protein expression was detected by RT-PCR and flow cytometry, respectively.

\section{HA treatment}

Six treatment groups were established: MCF-7 group, $\mathrm{MCF}-7+\mathrm{HA}$ treatment group, MCF-7/neo group, MCF-7/ CD44st group, CD44 blocking mAb pretreatment group, and MCF-7/CD44st+HA treatment group. MCF-7 cells in logarithmic growth phase were transfected with the recombinant plasmids pcDNA3.1-CD44st and pcDNA3.1. After $24 \mathrm{~h}$, the transfection solution was removed and $10 \%$ heatinactivated fetal bovine serum-supplemented 1640 medium was added. After $45 \mathrm{~h}$ of transfection, the cells were digested, centrifuged, and collected. For each group, $1.5 \times 10^{6}$ cells were counted and inoculated into culture flasks, and $1.5 \mathrm{~mL}$ of serum-free 1640 medium was added to the flasks. For the CD44 blocking mAb pretreatment, cells pretreated with $20 \mu \mathrm{g} / \mathrm{mL}$ of CD44 blocking mAb (R\&D Systems, Minneapolis, MN, USA) were incubated for $3 \mathrm{~h}$ with serum-free medium. For the MCF-7+HA group, MCF-7/ CD44st+HA group, and CD44 blocking mAb pretreatment group, HA $(100 \mu \mathrm{g} / \mathrm{mL})$ was added after $48 \mathrm{~h}$ of transfection and incubated for an additional $24 \mathrm{~h}$. To avoid contamination by other growth factors, HA was boiled at $100^{\circ} \mathrm{C}$ for $5 \mathrm{~min}$ before use. After $24 \mathrm{~h}$ of incubation, the cells in all groups were collected for RT-PCR detection.

\section{Detection of the CD44st, HER-2, and TGF $\beta$ mRNAs}

For each group, $1 \times 10^{6}$ cells were collected, and total RNA was extracted. cDNA was synthesized, and PCR was performed. Primer 5.0 was used to design the primers for human CD44st-1 (GeneBank: NO.AJ 216964), TGF $\beta$ (GeneBank: NO.NM_000660), and HER-2 (Cerb-B-2, GenBank: X03363.1). The primer sequences are shown in Table 1. Amplified products were separated by $1 \%$ agarose gel electrophoresis and analyzed using a gel image analyzer. The housekeeping gene $\beta$-actin was used as the internal reference for quality control and standardization.

\section{Detection of the TGF $\beta$, HER-2, AKT, and p-AKT proteins by Western blotting}

For each of the six groups, $1.0 \times 10^{6}$ cells were collected, boiled in $60 \mu \mathrm{L}$ of $2 \times$ loading buffer, and denatured at $100^{\circ} \mathrm{C}$ for $5 \mathrm{~min}$; proteins were separated by $12 \%$ SDS-PAGE. Semi-dry membrane transfer was performed at $1 \mathrm{~mA} / \mathrm{cm}^{2}$, and membranes were blocked with 5\% skim milk for $1 \mathrm{~h}$. glyceraldehyde-3-phosphate dehydrogenase $(1: 3,000)$ was 
Table I PCR primer sequences

\begin{tabular}{|c|c|c|c|}
\hline Genes & & Primer sequences & $\begin{array}{l}\text { Gene } \\
\text { products (bp) }\end{array}$ \\
\hline \multirow[t]{2}{*}{ CD44st-I } & Forward primer & 5'-GGATGGACAAGTTTTGGTGGCACG-3' & $\mathrm{I}, 023$ \\
\hline & Reverse primer & 5'-GGTTACACCCCAATCTTCATGTCC-3' & \\
\hline \multirow[t]{2}{*}{ CD44st-2 } & Forward primer & $5^{\prime}$-CCCTGCTACCAGACACTCA-3' & 281 \\
\hline & Reverse primer & 5'-TGTTCACCAAATGCACCAT-3' & \\
\hline \multirow[t]{2}{*}{ TGF $\beta$} & Forward primer & 5'-GGGACTATCCACCTGCAAGA-3' & 239 \\
\hline & Reverse primer & 5'-CCTCCTTGGCGTAGTAGTCG-3' & \\
\hline \multirow[t]{2}{*}{ HER-2 } & Forward primer & 5'-CTGGTGACACAGCTTATGCCCT-3' & 113 \\
\hline & Reverse primer & 5'-ATCCCCTTGGCAATCTGCA-3' & \\
\hline \multirow[t]{2}{*}{$\beta$-Actin } & Forward primer & 5'-CTCGCGCTACTCTCTCTTTC-3' & 330 \\
\hline & Reverse primer & 5'-CATGTCTCGATCCCACTTAAC-3' & \\
\hline
\end{tabular}

Abbreviations: TGF $\beta$, transforming growth factor $\beta$; HER-2, human epidermal growth factor receptor-2; PCR, polymerase chain reaction.

used as the internal control. Membranes were incubated in mouse anti-human TGF $\beta$, HER-2, AKT, or p-AKT antibodies (1:500) at $4^{\circ} \mathrm{C}$ overnight. Tris buffered saline with Tween 20 (TBST containing 1\% Tween-20) was used to wash the membrane three times (10 min each time). Goat anti-mouse secondary antibodies $(1: 2,000)$ were added and incubated at room temperature for $1 \mathrm{~h}$. The membrane was washed with TBST buffer, followed by addition of enhanced chemiluminescence luminescent reagent and exposure in Typhon.

\section{Test of tumor cell invasion by transwell migration assay}

Matrigel was diluted (1:1) in serum-free 1640 medium, and $150 \mu \mathrm{L}$ of the abovementioned mixture was added to each well (operating under low temperature) and incubated at $37^{\circ} \mathrm{C}$ for $1 \mathrm{~h}$. After Matrigel was fully polymerized, $1,000 \mu \mathrm{L}$ of 1640 medium containing 10\% newborn calf serum was added into the Transwell lower chamber and balanced for $1 \mathrm{~h}$. Experimental grouping was performed as already described. The cells in various experimental groups were digested with $0.25 \%$ trypsin and collected, and suspensions of $1 \times 10^{5}$ cells $/ \mathrm{mL}$ were prepared. Aliquots of $200 \mu \mathrm{L}$ of cell suspension were seeded into the Transwell upper chamber and cultured for $24 \mathrm{~h}$. The Transwell chambers were removed and Matrigel on the surface of the polycarbonate membrane was removed using a cotton swab. The upper and lower surfaces of the polycarbonate membrane were gently rinsed with PBS, dried, and stained with $0.1 \%$ crystal violet for $10 \mathrm{~min}$. Excess violet dye was removed and cells were observed under an optical microscope. Five 200× vision fields were randomly selected from each membrane, and the number of penetrating cells (the number of cells on the lower surface of the polycarbonate membrane) was counted. The number of penetrating cells represented the invasiveness of tumor cells. The experiment was repeated three times.
The role of the transcription factor AP-1 in the HA-CD44stTGF $\beta$-PI3K signaling pathway was studied by electrophoretic mobility shift assay (EMSA) as follows: $3 \times 10^{6} \mathrm{MCF}-7$ cells were counted and inoculated into culture flasks at $24 \mathrm{~h}$ before transfection. There were five groups: MCF-7 group, MCF-7/ CD44st group, MCF-7/CD44st+HA group, CD44 blocking $\mathrm{mAb}$ pretreatment group, and LY-294002 pretreatment group. After $24 \mathrm{~h}$ of transfection, the transfection mixture was removed, 1640 medium containing 10\% heat-inactivated fetal bovine serum was added, and cultures were incubated for $12 \mathrm{~h}$. After $36 \mathrm{~h}$ of transfection, the CD44 blocking mAb pretreatment group and the LY-294002 pretreatment group were pretreated with CD44 mAb $(20 \mu \mathrm{g} / \mathrm{mL})$ and LY-294002 (50 $\mu \mathrm{mol} / \mathrm{L})$ for $3 \mathrm{~h}$. After $39 \mathrm{~h}$ of transfection, HA $(100 \mu \mathrm{g} / \mathrm{mL})$ was added to the MCF-7/CD44st+HA, CD44 blocking mAb pretreatment, and LY-294002 pretreatment groups and incubated for $6 \mathrm{~h}$. The MCF-7/CD44st group was used as the negative control group. After $45 \mathrm{~h}$ of transfection, $6 \times 10^{6}$ cells of each group were collected and $300 \mu \mathrm{L}$ of cytoplasmic protein extraction Buffer A was added and incubated in ice for $15 \mathrm{~min}$. The mixture was centrifuged $\left(4^{\circ} \mathrm{C}\right.$ and $\left.15,000 \mathrm{rpm}\right)$ for $10 \mathrm{~min}$, the supernatants were discarded, $100 \mu \mathrm{L}$ of Buffer B was added and mixed evenly, and the mixture was incubated in an ice bath for $10 \mathrm{~min}$, mixed, and incubated again. This was repeated twice. The mixture was centrifuged at $4^{\circ} \mathrm{C}$ and $15,000 \mathrm{rpm}$ for $20 \mathrm{~min}$ and the supernatants were collect as the nuclear protein fraction. Aliquots of $2 \mu \mathrm{L}$ of the nuclear protein fraction were collected, and the protein concentration was determined by Bradford method. The nuclear protein fraction was aliquoted and stored at $-70^{\circ} \mathrm{C}$. The primer sequences for AP-1 were 5'-CGC TTG ATG ACT CAG CCG GAA-3' and 3'-GCG AAC TAC TGA GTC GGC CTT-5'. Probe labeling, ligation reaction, gel preparation, electrophoresis, membrane transfer, and chemiluminescence detection of biotin-labeled DNAs were performed according to the manuals of the corresponding 


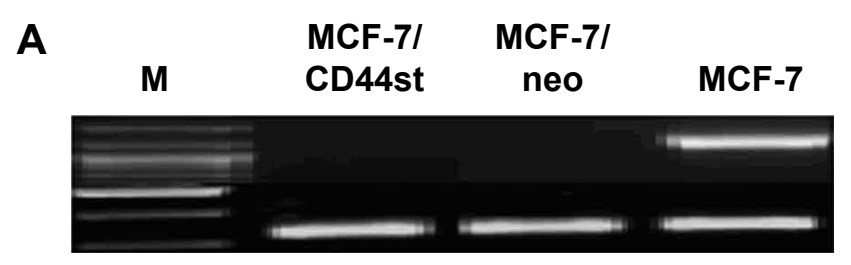

B

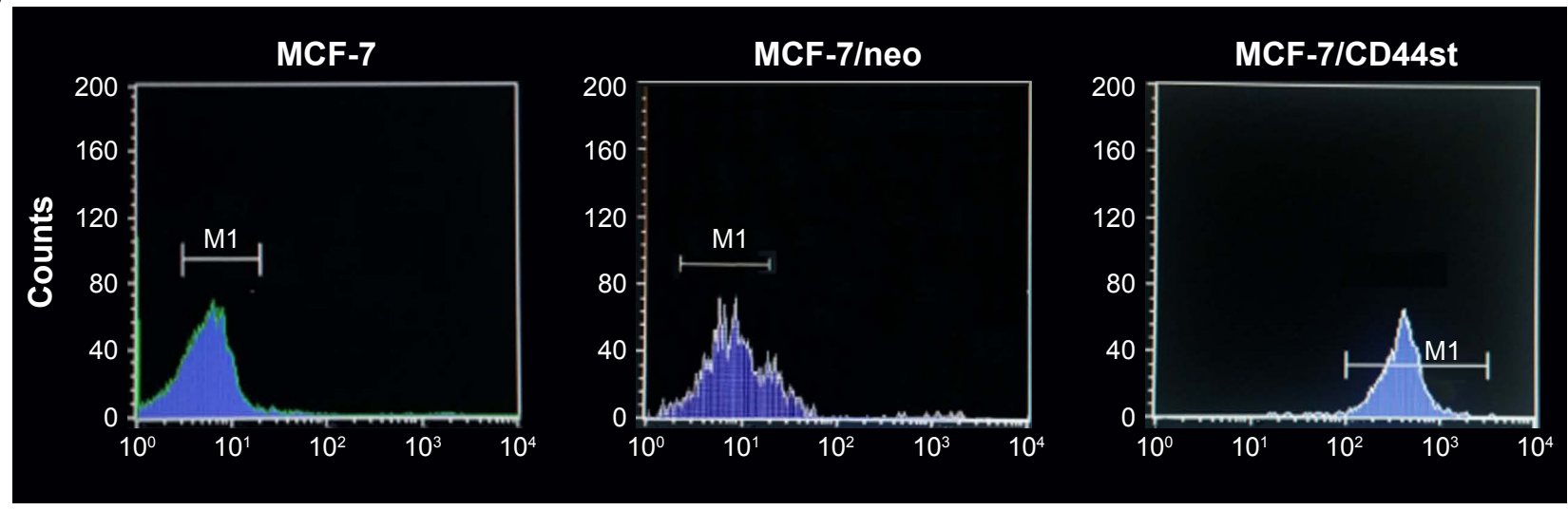

Figure I (A) Expression of CD44st mRNA in MCF-7 cells transfected with pcDNA3.I-CD44st with RT-PCR. (B) Expression of CD44st protein in MCF-7 cells transfected with pcDNA3.I-CD44st with flow cytometry.

Abbreviations: RT-PCR, reverse transcription-polymerase chain reaction; CD44st, short-tail isoform of CD44st.

kits. The membrane was exposed to X-ray. Exposure time was adjusted to obtain the best results.

RNA extraction of paraffin specimens, semiquantitative RT-PCR, and gene sequencing

Total RNAs of tumor tissues were extracted from paraffinembedded specimens using an RNA extraction kit (k1560-2). Primer sequences for CD44st-1 (GenBank: NO. FJ 216964) and HER-2 (GenBank: X03363.1) are shown in Figure 1. cDNA synthesis conditions were $65^{\circ} \mathrm{C}$ for $5 \mathrm{~min}$ and $37^{\circ} \mathrm{C}$ for $60 \mathrm{~min}$. PCR conditions were $94^{\circ} \mathrm{C}$ for $60 \mathrm{~s}, 54^{\circ} \mathrm{C}$ for $30 \mathrm{~s}$, $72^{\circ} \mathrm{C}$ for $60 \mathrm{~s}, 72^{\circ} \mathrm{C}$ for $10 \mathrm{~min}$, and 30 cycles to terminate the reaction. Gene sequencing was performed as previously described. ${ }^{3}$

\section{Real-time qPCR of CD44st and HER-2}

PCR primers for CD44st-2 and HER-2 are shown in Figure 1. The forward primer of $\beta$-actin was $5^{\prime}$-GCTGTGCTATCCCT GTACGC-3' and the reverse primer was $5^{\prime}$-TGCCTCAG GGCAGCGGAACC- $3^{\prime}$. The reaction system contained ddH2O $32.0 \mu \mathrm{L}$, dNTP $1.0 \mu \mathrm{L}, 10 \times$ buffer $5.0 \mu \mathrm{L}, \mathrm{MgCl} 2$ $(25 \mathrm{mM}) 4.0 \mu \mathrm{L}, 2.0 \mu \mathrm{L}$ of forward and reverse primers, Taq DNA polymerase $(5 \mathrm{U} / \mu \mathrm{L}) 2.0 \mu \mathrm{L}$, and cDNA template $2.0 \mu \mathrm{L}$. The total volume was $50 \mu \mathrm{L}$. Reaction conditions were $95^{\circ} \mathrm{C}$ predenaturation for $30 \mathrm{~s}, 95^{\circ} \mathrm{C}$ for $5 \mathrm{~s}$, $60^{\circ} \mathrm{C}$ for $1 \mathrm{~min}, 45$ cycles. Three duplicate wells were set up in each sample. $\beta$-Actin acted as an internal reference for normalization. qPCR reactions in this experiment were stable, reproducible, and had no nonspecific amplifications (Figures 2 and 3). The expression of the target gene relative to the internal reference $\beta$-actin was calculated using the following formula: $\Delta \mathrm{Ct}=\mathrm{Ct}_{\text {target gene }}-\mathrm{Ct}_{\beta \text {-actin }}$.

\section{Immunohistochemical analysis}

Immunohistochemistry was performed according to the instruction of the kit (SA2001; Shanghai Zemai Biotech Co, Ltd). On each slide, four high power fields (100 tumor cells/ high power field) were randomly selected. The positive rate of tumor cells was calculated as the sum of positive cells divided by 400 and graded as follows: $1:<25 \%$ of positive cells; $2: 26 \%-50 \% ; 3: 51 \%-75 \%$; and $4:>76 \%$. According to the staining intensity, light yellow was 1 point, brown yellow was 2 points, and dark brown was 3 points. The total score of the two parts was used to assess the results: $1-2$ points: -; 2-3 points:,$+ 4-5$ points: ++ , and $6-7$ points: $+++(\leq 3$ points: negative; $>3$ points: positive).

\section{Statistical analyses}

Statistical analyses were performed using SPSS 16.0 software (SPSS Inc., Chicago, IL, USA). Continuous data 


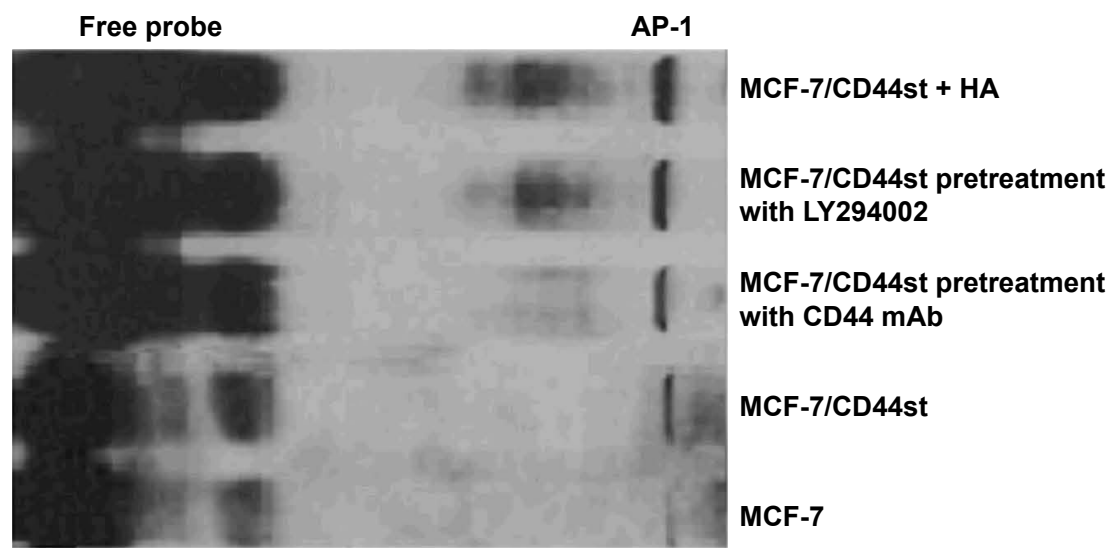

Figure 2 AP-I DNA binding activity as detected by EMSA.

Abbreviations: EMSA, electrophoretic mobility shift assay; CD44st, short-tail isoform of CD44s; HA, hyaluronic acid.

were expressed as mean $\pm \mathrm{SD}$. One-way analysis of variance (ANOVA) was used to analyze the difference between the transfection groups and the negative control group. One-way ANOVA was used to compare the means of multiple groups. The $q$ test was used for intergroup pairwise comparisons. The chi-squared test was used to analyze the differences in the positive expression rates of CD44st and HER-2 mRNA or protein in breast cancer tissues. The $\mathrm{K}-\mathrm{S}$ test showed that the $P$ values for the average $\Delta \mathrm{Ct}$ values of CD44st and HER-2 were 0.12 and 0.19 , which indicated that the data met normal distribution. The correlation between CD44 protein expression and the average $\Delta \mathrm{Ct}$ value of CD44st mRNA expression was evaluated using Spearman correlation analysis. The correlation between the expression of CD44st mRNA and HER-2 mRNA was also analyzed. $P<0.05$ was considered

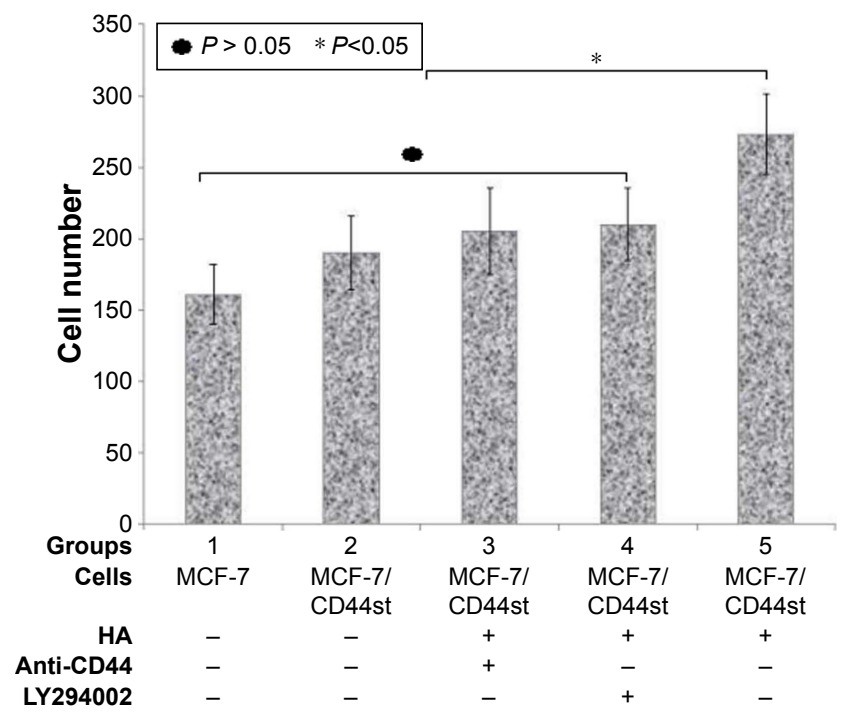

Figure 3 Invasion capability as detected by Transwell migration assay. Abbreviations: HA, hyaluronic acid; CD44st, short-tail isoform of CD44s. statistically significant. All participants provided written informed consent for their tissue samples to be used in the study. The study was approved and consented by the Ethics Committee of the Second People's Hospital of Lianyungang (Lianyungang Hospital Affiliated to Bengbu Medical College) (certificate no: 2016-048-01).

\section{Results}

\section{pcDNA3.I-CD44st plasmid transfection and expression in MCF-7 cells}

CD44st mRNA expression was not detected in MCF-7 and MCF/neo cells. However, CD44st mRNA was highly expressed in MCF-7/CD44st cells (Figure 1A). The results of flow cytometry showed that the expression rates of the CD44 protein in MCF-7, MCF-7/neo, and MCF-7/CD44st cells were $7.9 \% \pm 1.5 \%, 7.0 \% \pm 1.1 \%$, and $73.1 \% \pm 2.9 \%$, respectively. There were no significant differences in CD44 protein expression rates between MCF-7/neo cells and MCF-7 cells, whereas $\mathrm{CD} 44$ protein expression was significantly higher in MCF-7/CD44st cells than in MCF-7 cells or MCF-7/neo cells $(P<0.01$ for both, Figure 1B).

\section{CD44st-HA interaction upregulated TGF $\beta$ and HER-2 in MCF-7 cells}

HA treatment for $24 \mathrm{~h}$ significantly upregulated the mRNA and protein expression of TGF $\beta$ and HER- 2 in the MCF-7/ CD44st+HA treatment group, whereas it had no significant effect on the expression of TGF $\beta$ and HER-2 mRNA or protein in the MCF-7/CD44st group or the CD44 blocking $\mathrm{mAb}$ pretreatment group (Figure $4 \mathrm{~A}$ and $\mathrm{B}$ ). This suggested that the interaction between HA and CD44st upregulated the expression of TGF $\beta$ and HER-2. 


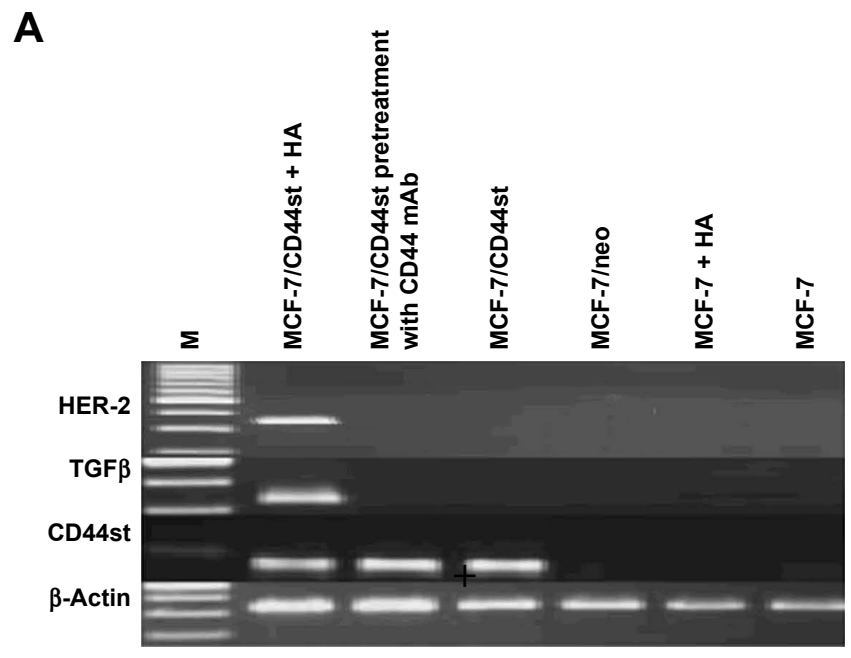

B

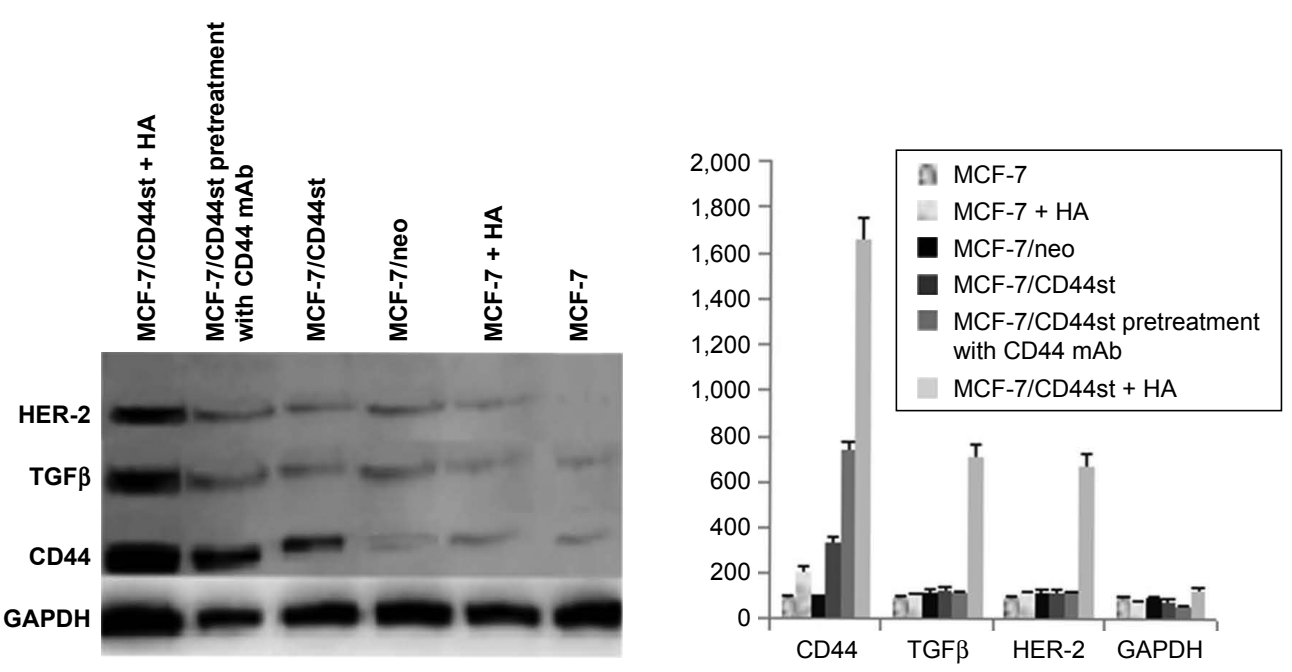

Figure 4 (A) Expression of CD44st, TGF $\beta$, and HER-2 mRNAs in each group of cells. (B) Expression of CD44st, TGF $\beta$, and HER-2 proteins in each group cells. Abbreviations: TGF $\beta$, transforming growth factor $\beta$; HER-2, human epidermal growth factor receptor; CD44st, short-tail isoform of CD44s; HA, hyaluronic acid; GAPDH, glyceraldehyde-3-phosphate dehydrogenase.

\section{HA activated the CD44st-TGF $\beta-P I 3 K$ signaling pathway}

HA treatment $(100 \mu \mathrm{g} / \mathrm{mL})$ for $30 \mathrm{~min}$ increased the expression of p-AKT in MCF-7 cells transfected with pcDNA3.1CD44st, whereas the expression of p-AKT in the CD44 blocking $\mathrm{mAb}$ pretreatment group was significantly weakened compared with that in the MCF-7/CD44st+HA treatment group. p-AKT expression did not change significantly in the other groups, which suggested that the interaction between HA and CD44st activated the PI3K signaling pathway when TGF $\beta$ expression was induced (Figure 5).

\section{Role of the transcription factor AP-I in the HA-CD44st-PI3K signaling pathway} EMSA was used to detect the binding of AP-1 to DNA. The fluorescence intensities of AP-1 binding to DNA were 750.7,
1,152.6, 2,261.8, 3,539.8, and 4,967.3 in the MCF-7, MCF-7/ CD44st, CD44 blocking mAb pretreatment, LY-294002 pretreatment, and MCF-7/CD44st+HA treatment groups, respectively (Figure 2).

\section{HA enhanced the invasiveness of MCF-7/ CD44st cells through the CD44st-PI3K signaling pathway}

The number of invasive cells was significantly higher in the MCF-7/CD44st+HA treatment group than in other groups $(P<0.05)$. The number of invasive cells was also higher in the pcDNA3.1-CD44st transfection group, CD44 blocking mAb pretreatment group, and LY-294002 pretreatment group than in the MCF-7 group, although the difference was not statistically significant $(P>0.05)$. This indicated that in response to HA, the activation of CD44st-PI3K plays an 

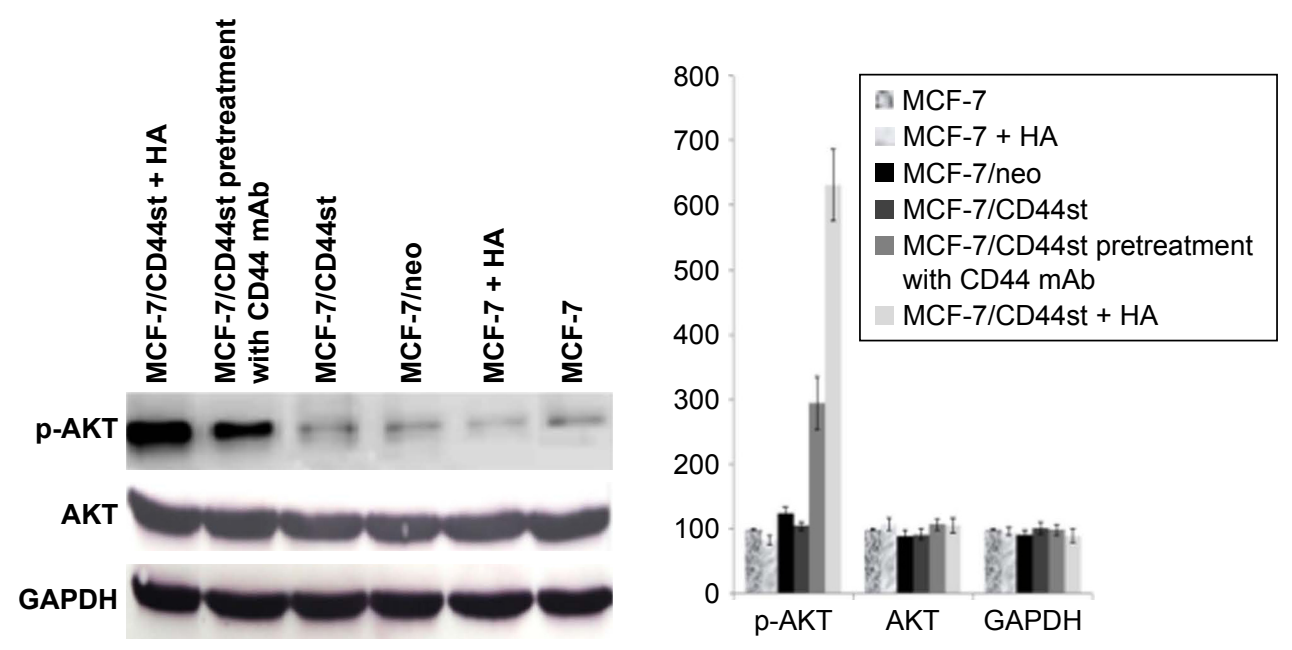

Figure 5 Expression of AKT and p-AKT regulated by HA-CD44st signaling pathways. Abbreviations: HA, hyaluronic acid; CD44st, short-tail isoform of CD44s; GAPDH, glyceraldehyde-3-phosphate dehydrogenase.

important role in the invasiveness of breast cancer MCF-7 cells (Table 2 and Figure 3).

\section{Expression of CD44st and HER-2 in breast cancer}

The CD44st and HER-2 mRNA and protein were not expressed in paracancerous tissues. Of 120 breast cancer specimens, $72(60 \%)$ were positive for CD44st mRNA and protein expression, and $48(40 \%)$ were negative. There were 30 cases (25\%) with positive expression of HER-2 mRNA and protein and 90 cases $(75 \%)$ with negative expression. Subgroup analysis showed that of the 72 CD44st-positive patients, 27 (37.5\%) were HER-2 positive and 45 (62.5\%) were HER-2 negative. Of 48 CD44st-negative patients, 3 (8.3\%) were HER-2 positive and 45 (91.7\%) were HER-2 negative. The difference in the expression of HER-2 between the CD44stpositive and CD44st-negative patient groups was statistically significant $(P<0.001$, Table 3 and Figures 6 and 7).

\section{Expression of CD44st mRNA and CD44 protein in breast cancer}

CD44 protein expression in breast cancer specimens detected by immunohistochemistry showed a score of 2-7 points.

Table 2 HA-CD44st signaling leads to an increase in MCF-7/ CD44st invasion capability

\begin{tabular}{ll}
\hline Groups & $\begin{array}{l}\text { Cells } \\
\text { (numbers/field) }\end{array}$ \\
\hline MCF-7 & $161 \pm 21$ \\
MCF-7/CD44st & $190 \pm 26$ \\
MCF-7/CD44 blocking mAb pretreatment & $205 \pm 30$ \\
MCF-7/CD44 LY-294002 pretreatment & $210 \pm 25$ \\
MCF-7/CD44st + HA treatment & $273 \pm 28$ \\
\hline
\end{tabular}

Abbreviations: HA, hyaluronic acid; mAb, monoclonal antibody; CD44st, shorttail isoform of CD44s.
The expression of the CD44st mRNA was expressed as the average $\Delta \mathrm{Ct}$ value. Spearman correlation analysis showed that CD44st mRNA expression was closely correlated with CD44 protein expression $(r=0.811, P=0.011)$.

\section{Correlation analysis of CD44st mRNA and HER-2 mRNA in breast cancer}

After normalization to the internal reference, the median $\Delta \mathrm{Ct}$ values in breast cancer tissues were 9.53 for the CD44st mRNA and 9.84 for the HER-2 mRNA. This indicated a linear correlation between the expression of CD44st and HER-2 $\left(R=0.965, R^{2}=0.931, F=1,672.6, P<0.001\right.$, Figure 8$)$.

\section{Discussion}

Studies confirmed that the expression of TGF $\beta$ family members (TGF $\beta 1$ and TGF $\beta 2$ ) and HA-CD44 signaling is closely associated with the invasion and metastasis of a variety of tumors. In breast cancer and lung cancer cells, TGF $\beta 1$ leads to reverse EGF signaling activation and induces EMT through HA-CD44, which affects the invasion and metastasis of tumor cells and tumor progression. ${ }^{21,22} T G F \beta 2$ is a potential CD44 downstream gene, which can activate JNK/ AP-1-signaling. ${ }^{23}$ In breast cancer MCF-7 cells with positive expression of CD44 (B5 clone), pretreatment with HA results in the significant upregulation of the TGF $\beta 2$ precursor protein, whereas treatment with CD44 RNAi significantly

Table 3 Expression of CD44st and HER-2 in breast cancer (\%)

\begin{tabular}{llll}
\hline Group & $\mathbf{n}$ & HER-2+ & HER-2- \\
\hline CD44st + & 72 & $27(37.5)$ & $45(62.5)$ \\
CD44st- & 48 & $3(6.2)$ & $45(93.8)$ \\
\hline
\end{tabular}

Note: $P<0.001$.

Abbreviations: HER-2, human epidermal growth factor receptor-2; CD44st, short-tail isoform of CD44s. 


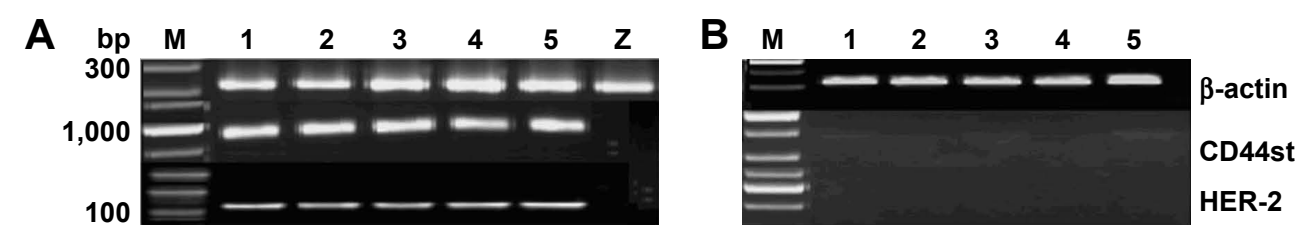

Figure 6 Expression of CD44st and HER-2 mRNA in breast cancer tissues and paracancerous tissues.

Note: I-5: Breast cancer tissues and paracancerous tissues from five different patients, Z: control group, (A) cancer tissues, (B) peri-carcinoma tissues.

Abbreviations: HER-2, human epidermal growth factor receptor-2; CD44st, short-tail isoform of CD44s.

downregulates TGF $\beta 2$ expression. This suggests that TGF $\beta 2$ is a downstream target gene of the HA/CD44 signaling pathway, which is associated with the invasiveness and drug resistance of breast cancer cells. ${ }^{10,24}$ Studies showed that the overexpression of TGF $\beta 2$ contributes to the invasion of many tumors, such as ovarian cancer, ${ }^{25}$ melanoma ${ }^{26}$ pancreatic cancer, ${ }^{27}$ and skin cancer. ${ }^{28}$
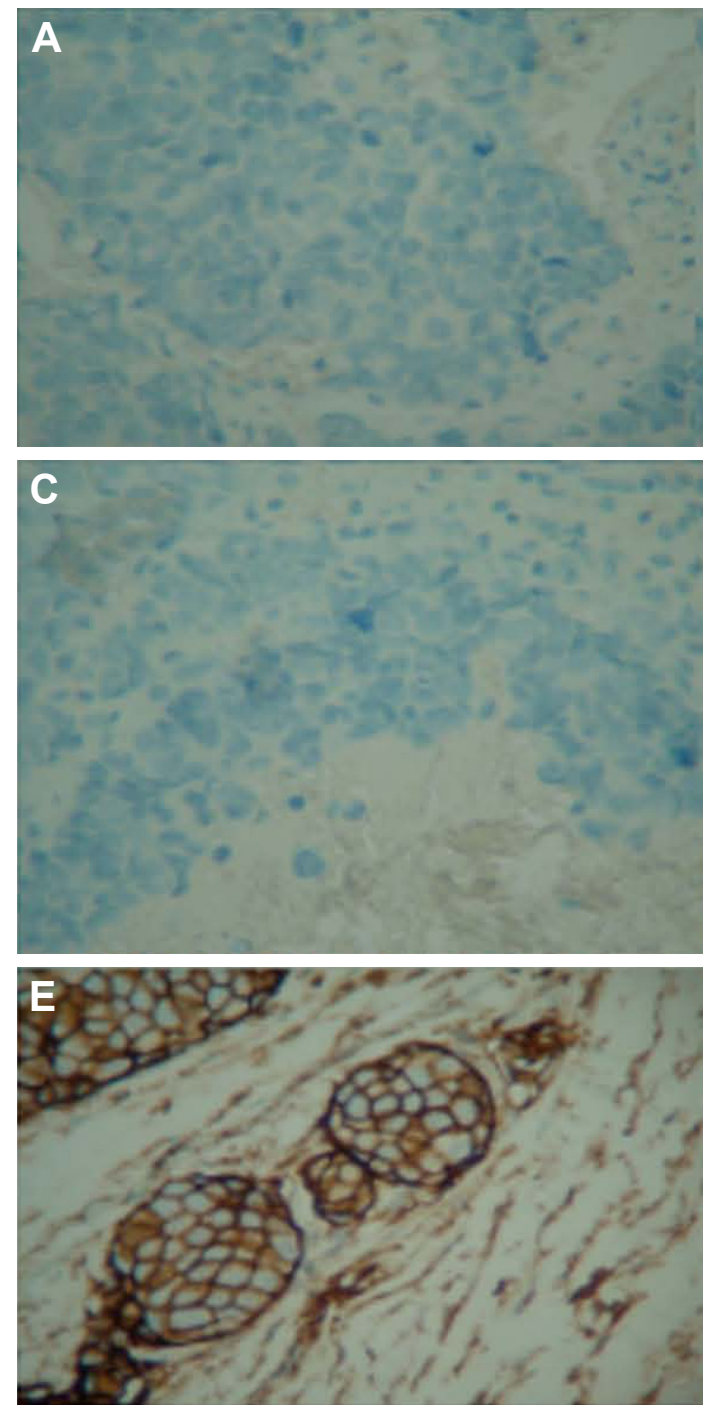

Figure 7 Expression of CD44st and HER-2 proteins in breast cancer tissues $(\times 400)$.

Note: (A) CD44 negative (blank control), (B) HER-2 negative (blank control), (C) CD44 negative (negative control), (D) HER-2 negative (negative control), (E) CD44 positive, and (F) HER-2 positive.

Abbreviations: HER-2, human epidermal growth factor receptor-2; CD44st, short-tail isoform of CD44s.
In this study, CD44 detecting mAb could detect all CD44 family members. When eukaryotic expression vector pcDNA3.1-CD44st was transfected into MCF-7 cells by Lipofectamine, upregulated levels of the CD44st gene mRNA and CD44 protein were detected. Therefore, the upregulated CD44 protein in MCF-7/CD44st cells could be regarded as a result of the expression of CD44st mRNA. We also showed
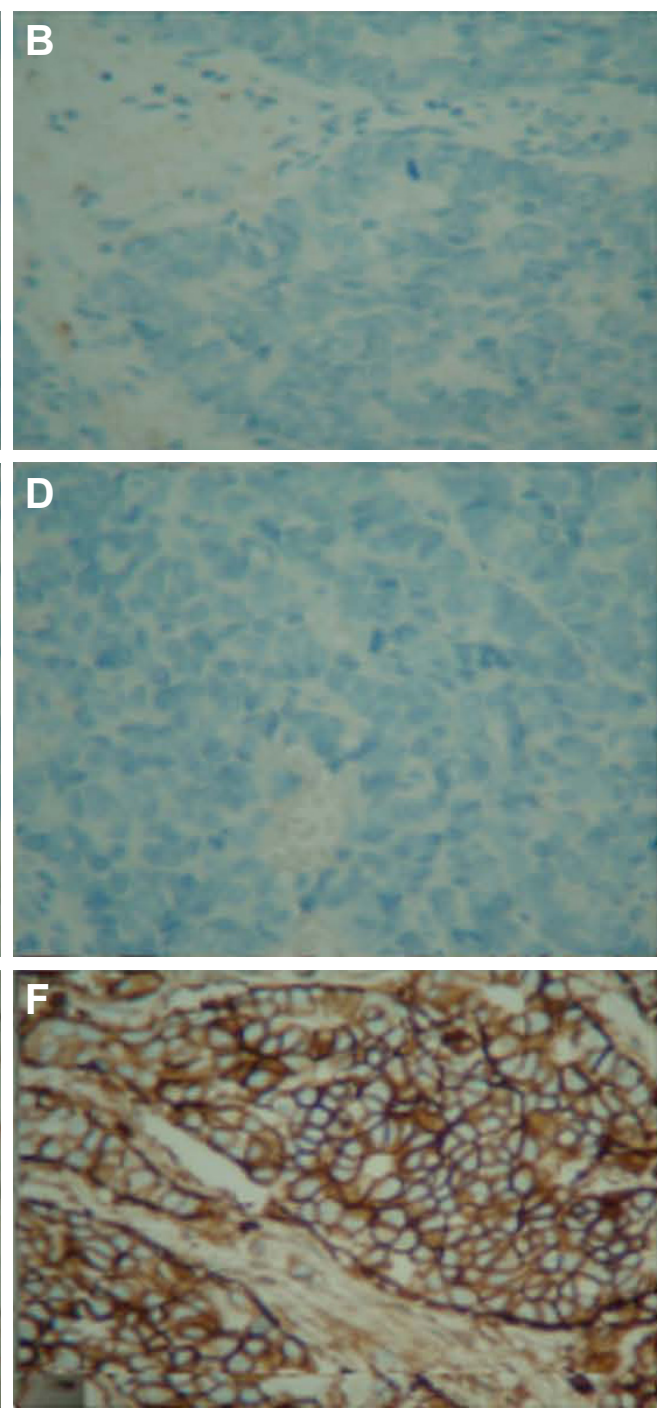


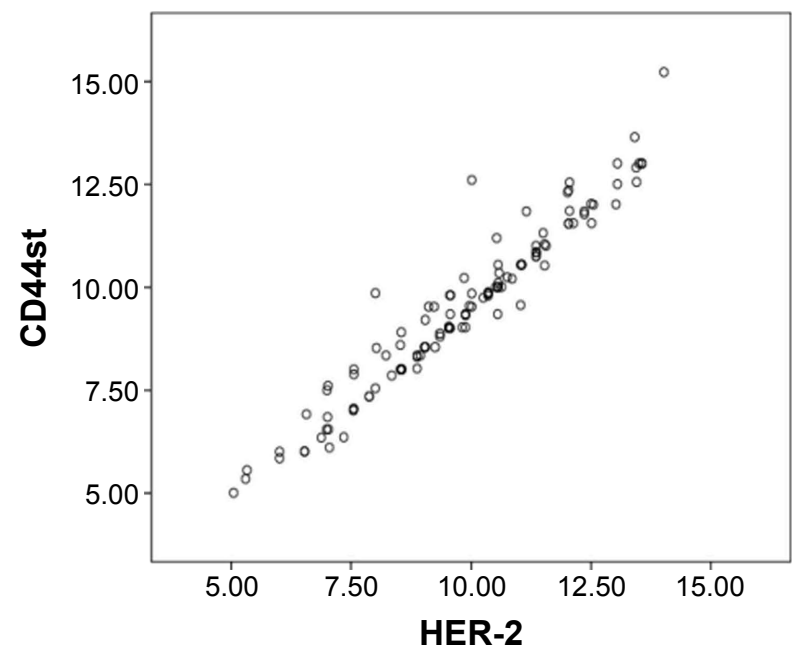

Figure 8 Relationship between CD44st and HER-2 mRNAs in breast cancer tissues. Abbreviations: HER-2, human epidermal growth factor receptor-2; CD44st, short-tail isoform of CD44s.

that the binding of HA to CD44st might modulate the invasiveness of MCF-7 cells through CD44st/TGF $\beta / \mathrm{PI} 3 \mathrm{~K} / \mathrm{AP}-1$ signaling concomitant. Therefore, TGF $\beta$ is likely to be one of the downstream signaling proteins of HA-CD44st, and the interaction between HA and CD44st plays an important role in the expression of HER-2 as well as the invasiveness of $\mathrm{MCF}-7$ cells.

In recent years, studies investigating the expression and significance of CD44 in breast cancer showed that during tumor progression, HA binds to CD44 subtypes that are widely distributed on the cell surface to induce the expression of cytoskeletal proteins such as ankyrin and small $\mathrm{G}$ protein Rho and the activation of the PI3K-AKT pathway, which promotes the adhesion, growth, proliferation, migration, and invasiveness of MCF-7 cells. ${ }^{29}$

The interaction between HA and CD44 also contributes to the resistance of HER-positive breast cancer cells to trastuzumab ${ }^{20}$ and is associated with poor prognosis in breast cancer patients. ${ }^{30-33}$ Recent studies reported that the binding of HA to CD44 can modulate the activity of EGFR family members. ${ }^{14}$ The serum CD44 concentration was a significant predictor of overall survival for patients with HER-2-positive breast cancer, which suggested that CD44 should be investigated further for its potential as a prognostic biomarker. ${ }^{34}$ Bellerby et al confirmed that CD44 overexpression is associated with resistance to endocrine therapeutics and that it increases the invasiveness of estrogen-resistant cells. In estrogen-sensitive MCF-7 cells, CD44v6 overexpression enhances the invasion of tumor cells and decreases the response to estrogen drugs through the reverse activation of the EGFR signaling pathway. Targeted therapy against
CD44v6 or EGFR could delay or prevent drug resistance of breast cancer cells. ${ }^{35}$ In a study including 273 postoperative breast cancer patients, the expression of HA in cancer cells and the expression of CD44 in stromal cells were significantly higher in HER-2-positive patients than in HER-2-negative patients. Moreover, CD44 positivity in stromal cells and HER-2 positivity in breast cancer cells were closely associated with negative estrogen receptor expression and poor differentiation of the cancer and affected the prognosis of postoperative breast cancer patients. This study also highlighted the correlation between HER-2 expression and HA and CD44 expression in tumor cells. ${ }^{36}$

The expression of CD44 is closely associated with the molecular classification of breast cancer and it affects the prognosis of patients. Members of the CD44 family such as CD44v and CD44s play an important role in the progression of breast cancer. CD44v-positive breast cancer, which is associated with the luminal A molecular subtype, has a relatively good prognosis. Additionally, CD44s expression is correlated with HER-2 status and the basal-like subtype, ${ }^{37,38}$ whereas high expression of CD44v2-v10 is correlated with estrogen receptor expression, high differentiation, and luminal A subtype. Positive expression of CD44v8-v10 and EGFR accompanied by low expression of HER2 is correlated with the basal-like subtype. ${ }^{38}$ Bellerby et al showed that CD44 overexpression is involved in estrogen resistance and promotes the invasiveness of drug-resistant tumor cells. In estrogen-sensitive MCF-7 cells, CD44v6 overexpression enhances the invasion of tumor cells and reduces the response to estrogen through the reverse activation of the EGFR signaling pathway. Targeted therapy against CD44v6 and EGFR can delay or prevent breast cancer resistance. ${ }^{35}$

The results of the present study suggest that the interaction between HA and CD44st is critical for the regulation of TGF $\beta$ and HER2 expression as well as PI3K signal transduction. HA treatment significantly increased the fluorescence intensity of AP-1 binding to the corresponding probes. The fluorescence intensity was significantly weakened by pretreatment with the CD44 blocking mAb and PI3K signaling pathway inhibitor. TGF $\beta 2$ acts as a potential CD44 downstream gene through activating JNK/AP-1-signaling. ${ }^{23}$ The results indicated that HA could significantly enhance the activity of AP-1, and this effect was inhibited by the CD44 blocking $\mathrm{mAb}$ and the $\mathrm{PI} 3 \mathrm{~K}$ pathway inhibitor. The interaction of the HA-CD44st/TGF $\beta / \mathrm{PI} 3 \mathrm{~K} / \mathrm{AP}-1$ signaling cascade and the signals mediated by TGF $\beta$ affects the growth, proliferation, and malignant phenotypes of breast cancer cells. The results of this study also summarized that the CD44st 
and HER-2 positivity is expressed in some breast cancer specimens, but not in paracancerous tissues. Moreover, the study found a linear correlation between the expression of CD44st and the expression of HER-2 in breast cancer tissue. In our future studies, the CD44st mAb will be developed, and we will detect the differential expression of CD44st, CD44, and CD44v6 in breast cancer tissues by immunohistochemistry; the influence of the biological behavior and prognosis by differential expression among the CD44 family members will also be discussed in breast cancer.

In summary, the present study provides a theoretical basis for the development of molecular therapy targeting CD44st, TGF $\beta$, and the abovementioned pathways. Further in-depth studies are needed to elucidate the detailed mechanisms underlying the role of these pathways in oncogenesis, drug resistance, and the invasive behavior of breast cancer.

\section{Acknowledgments}

This study was funded by the " 333 " talents projects of Jiangsu province (project number: BRA 2016299), The Science and Technology Department of Lianyungang (project number: SH1415), The Health and Family Planning Commission of Jiang su Province (project number: H2017040), and "521" Talent Project of Lianyungang.

\section{Author contributions}

LYZ contributed to the experimental research. XJF funded the experiment and contributed to the study design. HGH contributed to data collection of the test and part of experimental research. LJJ contributed to the data analysis. ZX contributed to the study design. All authors contributed toward data analysis, drafting and revising the paper and agree to be accountable for all aspects of the work.

\section{Disclosure}

The authors report no conflicts of interest in this work.

\section{References}

1. Orian-Rousseau V. CD44 acts as a signaling platform controlling tumor progression and metastasis. Front Immunol. 2015;6:154.

2. Thorne RF, Legg JW, Isacke CM. The role of the CD44 transmembrane and cytoplasmic domains in co-ordinating adhesive and signalling events. J Cell Sci. 2004;117(Pt 3):373-380.

3. Fang XJ, Jiang H, Zhao XP, Jiang WM. The role of a new CD44st in increasing the invasion capability of the human breast cancer cell line MCF-7. BMC Cancer. 2011;11:290.

4. Fang XJ, Jiang H, Zhu YQ, Zhang LY, Fan QH, Tian Y. Doxorubicin induces drug resistance and expression of the novel CD44st via NF-אB in human breast cancer MCF-7 cells. Oncol Rep. 2014;31(6): $2735-2742$.
5. Rojas A, Padidam M, Cress D, Grady WM. TGF-beta receptor levels regulate the specificity of signaling pathway activation and biological effects of TGF-beta. Biochim Biophys Acta. 2009;1793(7):1165-1173.

6. Pannu J, Gore-Hyer E, Yamanaka M, et al. An increased transforming growth factor beta receptor type I:type II ratio contributes to elevated collagen protein synthesis that is resistant to inhibition via a kinasedeficient transforming growth factor beta receptor type II in scleroderma. Arthritis Rheum. 2004;50(5):1566-1577.

7. Wakefield LM, Roberts AB. TGF-beta signaling: positive and negative effects on tumorigenesis. Curr Opin Genet Dev. 2002;12(1):22-29.

8. Robertson IB, Horiguchi M, Zilberberg L, Dabovic B, Hadjiolova K, Rifkin DB. Latent TGF- $\beta$-binding proteins. Matrix Biol. 2015;47: 44-53.

9. Meran S, Luo DD, Simpson R, et al. Hyaluronan facilitates transforming growth factor- $\beta 1$-dependent proliferation via $\mathrm{CD} 44$ and epidermal growth factor receptor interaction. J Biol Chem. 2011;286(20):17618-17630.

10. Ouhtit A, Madani S, Gupta I, et al. TGF- $\beta 2$ : a novel target of CD44promoted breast cancer invasion. J Cancer. 2013;4(7):566-572.

11. Kalluri R, Weinberg RA. The basics of epithelial-mesenchymal transition. J Clin Invest. 2009;119(6):1420-1428.

12. Puisieux A, Brabletz T, Caramel J. Oncogenic roles of EMT-inducing transcription factors. Nat Cell Biol. 2014;16(6):488-494.

13. Zhang YE. Non-Smad pathways in TGF-beta signaling. Cell Res. 2009; 19(1):128-139.

14. Heldin CH, Miyazono K, ten Dijke P. TGF-beta signalling from cell membrane to nucleus through SMAD proteins. Nature. 1997;390(6659): 465-471.

15. Slamon DJ, Clark GM, Wong SG, Levin WJ, Ullrich A, McGuire WL. Human breast cancer: correlation of relapse and survival with amplification of the HER-2/neu oncogene. Science. 1987;235(4785):177-182.

16. Yu Q, Zhu Z, Liu Y, Zhang J, Li K. Efficacy and safety of HER2-targeted agents for breast cancer with HER2-overexpression: a network metaanalysis. PLoS One. 2015;10(5):e0127404.

17. Del Mastro L, Lambertini M, Bighin C, et al. Trastuzumab as first-line therapy in HER2-positive metastatic breast cancer patients. Expert Rev Anticancer Ther. 2012;12(11):1391-1405.

18. Ghatak S, Misra S, Toole BP. Hyaluronan constitutively regulates ErbB2 phosphorylation and signaling complex formation in carcinoma cells. J Biol Chem. 2005;280(10):8875-8883.

19. Bourguignon LY, Zhu H, Zhou B, Diedrich F, Singleton PA, Hung MC Hyaluronan promotes CD44v3-Vav2 interaction with Grb2-p185(HER2) and induces Rac1 and Ras signaling during ovarian tumor cell migration and growth. J Biol Chem. 2001;276(52):48679-48692.

20. Boulbes DR, Chauhan GB, Jin Q, Bartholomeusz C, Esteva FJ. CD44 expression contributes to trastuzumab resistance in HER2-positive breast cancer cells. Breast Cancer Res Treat. 2015;151(3):501-513.

21. Li L, Qi L, Liang Z, et al. Transforming growth factor- $\beta 1$ induces EMT by the transactivation of epidermal growth factor signaling through HA/CD44 in lung and breast cancer cells. Int J Mol Med. 2015;36(1): $113-122$.

22. Quan J, Elhousiny M, Johnson NW, Gao J. Transforming growth factor- $\beta 1$ treatment of oral cancer induces epithelial-mesenchymal transition and promotes bone invasion via enhanced activity of osteoclasts. Clin Exp Metastasis. 2013;30(5):659-670.

23. Haidar M, Whitworth J, Noé G, Liu WQ, Vidal M, Langsley G. TGF- $\beta 2$ induces Grb2 to recruit PI3-K to TGF-RII that activates JNK/ AP-1-signaling and augments invasiveness of Theileria-transformed macrophages. Sci Rep. 2015;5:15688.

24. Siobhan K O'Brien, Chen L, Zhong W, et al. Breast cancer cells respond differentially to modulation of TGF- $\beta 2$ signaling after exposure to chemotherapy or hypoxia. Cancer Res. 2015;75(21):4605-4616.

25. Do TV, Kubba LA, Du H, Sturgis CD, Woodruff TK. Transforming growth factor-beta1, transforming growth factor-beta2, and transforming growth factor-beta 3 enhance ovarian cancer metastatic potential by inducing a Smad3-dependent epithelial-to-mesenchymal transition. Mol Cancer Res. 2008;6(5):695-705. 
26. Zhang C, Zhang F, Tsan R, Fidler IJ. Transforming growth factor-beta 2 is a molecular determinant for site-specific melanoma metastasis in the brain. Cancer Res. 2009;69(3):828-835.

27. Hilbig A, Oettle H. Transforming growth factor beta in pancreatic cancer. Curr Pharm Biotechnol. 2011;12(12):2158-2164.

28. Davies M, Prime SS, Eveson JW, et al. Transforming growth factor- $\beta$ enhances invasion and metastasis in Ras-transfected human malignant epidermal keratinocytes. Int J Exp Pathol. 2012;93(2):148-156.

29. Nam K, Oh S, Lee KM, Yoo SA, Shin I. CD44 regulates cell proliferation, migration, and invasion via modulation of c-Src transcription in human breast cancer cells. Cell Signal. 2015;27(9):1882-1894.

30. Chekhun SV, Zadvorny TV, Tymovska YO, Anikusko MF, Novak OE, Polishchuk LZ. CD44+/CD24- markers of cancer stem cells in patients with breast cancer of different molecular subtypes. Exp Oncol. 2015; 37(1):58-63.

31. Seo AN, Lee HJ, Kim EJ, et al. Expression of breast cancer stem cell markers as predictors of prognosis and response to trastuzumab in HER2-positive breast cancer. Br J Cancer. 2016;114(10):1109-1116.

32. Qiu Y, Pu T, Guo P, et al. ALDH(+)/CD44(+) cells in breast cancer are associated with worse prognosis and poor clinical outcome. Exp Mol Pathol. 2016;100(1):145-150.
33. Zheng Z, Shao N, Weng H, et al. Correlation between epidermal growth factor receptor and tumor stem cell markers CD44/CD24 and their relationship with prognosis in breast invasive ductal carcinoma. Med Oncol. 2015;32(1):275.

34. Baek JM, Jin Q, Ensor J, Boulbes DR, Esteva FJ. Serum CD44 levels and overall survival in patients with HER2-positive breast cancer. Breast Cancer Res Treat. 2011;130(3):1029-1036.

35. Bellerby R, Smith C, Kyme S, et al. Overexpression of specific CD44 isoforms is associated with aggressive cell features in acquired endocrine resistance. Front Oncol. 2016;6:145.

36. Auvinen P, Tammi R, Kosma M, et al. Increased hyaluronan content and stromal cell CD44 associate with HER2 positivity and poor prognosis in human breast cancer. Int J Cancer. 2013;132(3):531-539.

37. Inoue K, Fry EA. Aberrant splicing of estrogen receptor, HER2, and CD44 genes in breast cancer. Genet Epigenet. 2015;7:19-32.

38. Olsson E, Honeth G, Bendahl PO, et al. CD44 isoforms are heterogeneously expressed in breast cancer and correlate with tumor subtypes and cancer stem cell markers. BMC Cancer. 2011;11:418.
OncoTargets and Therapy

\section{Publish your work in this journal}

OncoTargets and Therapy is an international, peer-reviewed, open access journal focusing on the pathological basis of all cancers, potential targets for therapy and treatment protocols employed to improve the management of cancer patients. The journal also focuses on the impact of management programs and new therapeutic agents and protocols on

\section{Dovepress}

patient perspectives such as quality of life, adherence and satisfaction. The manuscript management system is completely online and includes a very quick and fair peer-review system, which is all easy to use. Visit http://www.dovepress.com/testimonials.php to read real quotes from published authors. 